\title{
Intestinal Malrotation Confused with Psychiatric Disorder in a Child: A Case Report
}

\author{
Çocukta Psikiyatrik Bozukluk ile Karışan İntestinal Malrotasyon Olgusu
}

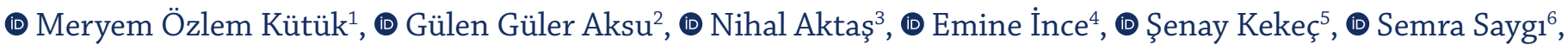

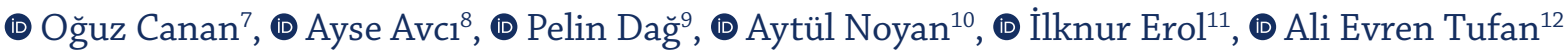

${ }^{1}$ Başkent University Faculty of Medicine, Dr. Turgut Noyan Medical and Research Center, Department of Child and Adolescent Psychiatry, Adana, Turkey

${ }^{2}$ Mersin University Faculty of Medicine, Department of Child and Adolescent Psychiatry, Mersin, Turkey

${ }^{3}$ Başkent University Faculty of Medicine, Dr. Turgut Noyan Medical and Research Center, Department of Pediatrics, Adana, Turkey

${ }^{4}$ Başkent University Faculty of Medicine, Dr. Turgut Noyan Medical and Research Center, Department Of Pediatric Surgery, Adana, Turkey

${ }^{5}$ Başkent University Faculty of Medicine, Dr. Turgut Noyan Medical and Research Center, Department of Radiology, Adana, Turkey

${ }^{6}$ Başkent University Faculty of Medicine, Dr. Turgut Noyan Medical and Research Center, Department of Pediatric Neurology, Adana, Turkey

${ }^{7}$ Başkent University Faculty of Medicine, Dr. Turgut Noyan Medical and Research Center, Department of Pediatrics, Pediatric Gastroenterology, Hepatology And Nutrition Unit,

${ }^{8}$ Child and Adolescent Psychiatrist, Private Practice, Adana, Turkey

${ }^{9}$ Mersin City Training and Research Hospital, Clinic of Child and Adolescent Psychiatry, Mersin, Turkey

${ }^{10}$ Başkent University Faculty of Medicine, Seyhan Medical Center, Department of Child Urology, Adana, Turkey

${ }^{11}$ Başkent University Faculty of Medicine, Seyhan Medical Center, Department of Pediatric Neurology, Adana, Turkey

${ }^{12}$ Acıbadem University Faculty of Medicine, Department of Child and Adolescent Psychiatry, İstanbul, Turkey

We aim to explore the importance of early differential diagnosis of an organic etiology such as intestinal malrotation and psychiatric disorder. We present a child with an intestinal malrotation, who had no symptoms until she was 4 year old. The child presented with sudden cessation of oral food intake and constipation. The diagnosis was missed at another center, as there were many accompanying psychiatric symptoms. The child improved after surgery, and the severity of the psychiatric symptoms decreased. This case emphasizes that an organic disorder can be confused with a mental disorder. Many patients with intestinal malrotation present with abdominal discomfort since childhood, while others present with relatively sudden onset of symptoms. The clinician should consider all symptoms to avoid missing that important and treatable condition.

Keywords: Intestinal malrotation, child psychiatry, eating disorder

Bu olguda psikiyatrik bozukluk ve intestinal malrotasyonun erken ayırıcı tanısının önemini vurgulamayı amaçlıyoruz. Dört yaşına kadar herhangi bir semptomu olmayan intestinal malrotasyonu olgusunu sunmaktayız. Ani gelişen oral gıda alımı reddi ve kabızlık ile prezente olan, birçok psikiyatrik semptomun eşlik ettiği bu olguda tanının başka bir merkezde atlandığı gözlendi. Olgu ameliyattan sonra düzeldi ve psikiyatrik semptomların şiddeti azaldı. Bu durum organik bir hastalığın zihinsel bir bozuklukla karıştırılabileceğini vurgulamaktadır. İntestinal malrotasyonu olan birçok hastada çocukluktan beri karında rahatsızlık hissi görülürken, bazen nispeten semptomların ani başlangıcı görülmektedir. Klinisyen, bu önemli ve tedavi edilebilir durumu kaçırmamak için tüm belirtileri göz önünde bulundurmalıdır.

Anahtar Kelimeler: İntestinal malrotasyon, çocuk psikiyatri, yeme bozukluğu

\section{Introduction}

Intestinal malrotation is a rotation and fixation anomaly of the intestines. About $90 \%$ of intestinal malrotation cases are diagnosed during the first year of life or early childhood. ${ }^{1}$ Marked symptoms in children are stomachache, bilious vomiting, and distension. ${ }^{2}$ Sometimes atypical and unspecific nature of the symptoms can make diagnosis more complicated and lead to inappropriate treatment..$^{2-6}$

We present a child with intestinal malrotation, who had no symptoms until she was 4 years old and presented with sudden cessation of oral food intake. The diagnosis was missed at another center, as there were many accompanying psychological

Address for Correspondence/Yazıșma Adresi: Gülen Güler Aksu MD, Mersin University Faculty of Medicine, Department of Child and Adolescent Psychiatry, Mersin, Turkey

Phone: +90 5075093592 E-mail: dr.gulen@hotmail.com ORCID: orcid.org/0000-0001-9555-3916

Received/Geliș Tarihi: 24.11.2019 Accepted/Kabul Tarihi: 17.02.2020

${ }^{\circ}$ Copyright 2020 by the Turkish Association for child and Adolescent Psychiatry / Turkish Journal of Child and Adolescent Mental Health. published by Galenos Publishing House. 
symptoms. The patient improved after surgery, and the severity of the psychiatric symptoms decreased.

\section{Case Report}

A 4-year-old girl was admitted to the pediatric outpatient clinic of our hospital with the complaints of refusing to eat, lack of appetite without stomachache and vomiting for about one month.

Her mother stated that she had declined to eat and had begun psychological withdrawal starting about one month ago when her father hit her during a fight with her siblings. Firstly, she was referred to a child psychiatrist in another center where she was diagnosed with an eating disorder not otherwise specified. Fluoxetine and risperidone were prescribed in that center. After one week, the parents applied to pediatric emergency service because of increasing severity of the symptoms. At the emergency service, the pediatrician explored two abrasions on the sacrum, which occurred when her father slapped her for fighting with her siblings. Then, the child was consulted by a forensic physician who thought that physical abuse might have occurred, so the case was evaluated legally. The child and adolescent psychiatry department followed the patient during this admission at the service and risperidone ( $0.5 \mathrm{mg} /$ day) was recommended again. The family demanded hospital discharge on day 11 of admission. One week after discharge, the patient was admitted to our clinic.

Physical examination revealed alert consciousness. Malnourishment and a slightly dehydrated appearance were also noted. She did not have eye contact and initially did not allow physical examination. As a physical examination could be carried out, no abdominal tenderness, any organomegaly or rebound phenomenon were detected.

Whole blood count, urinalysis, liver, pancreatic and kidney function tests were all normal. Her height was $108 \mathrm{~cm}\left(50^{\text {th }}\right.$ $75^{\text {th }}$ percentile), and body weight was $14.2 \mathrm{~kg}$ ( $<3^{\text {rd }}$ percentile). Her body mass index was $12.2 \mathrm{~kg} / \mathrm{m}^{2}$ (severe malnutrition). At the time of admission, her blood sugar level was $50 \mathrm{mg} / \mathrm{dL}$, so glucose was infused. Nutrition was maintained with enteral food products via a nasogastric catheter. An abdominal ultrasonograpy examination was normal. The neurological examination was evaluated as normal at the same time. Child psychiatrist commented that she sat on mother's lap and made no eye contact, did not answer questions and cried. Her mother told that after slapping, she had refused to eat and to drink gradually, and she tried to feed people around her and watch them while eating. She also licked food, touched them and asked the mother to repeat her behaviors, such as touching and stepping. She was always near the mother. The presumptive diagnoses of post-traumatic stress disorder (associated with physical abuse), eating disorder not otherwise specified, and obsessive compulsive disorder were considered as initial diagnoses according to DSM-5, but no treatment was recommended until all organic examinations were done.
Then, upper gastrointestinal imaging graph was taken as a result of consultation with pediatric gastroenterology. In the graph, the duodenum did not follow its normal course after the third part and on the slightly right side of the midline, turned towards casual, suggesting malrotation (Figure 1). An operation was planned after consultation with pediatric surgery. Malrotation was identified during surgery and Ladd's procedure was carried out. Oral feeding was started on postoperative day 7. The psychiatric evaluation repeated 15 days after discharge in the outpatient clinic showed a happy girl. She played and drew pictures at the clinic. After discharge, the family stated that her obsessions and nervous behavior were alleviated.

\section{Discussion}

Children are likely to be very distressed and withdrawn immediately after a frightening experience. Separation difficulties are common in these children, and many children become anxious, irritable, and disturbed. They can also have concentration difficulties, memory problems, and sleep and eating problems. ${ }^{7}$

Similarly, in the present patient, complaints and behaviors such as refusing the separation from the mother, sleeping with the mother, nervousness, withdrawal, not engaging in normal activities, sadness, and refusing to eat and drink after she had been beaten by her father suggested post-traumatic stress disorder. However, intestinal malrotation was detected on upper gastrointestinal imaging graph, and Ladd's procedure was performed. Her intestinal symptoms improved, and she started oral food intake postoperatively.

Rotational anomalies are seen as a consequence of stopping of normal rotation of the embryonic gut. As rotational anomalies can remain asymptomatic throughout life, the true incidence is not known. ${ }^{1,8}$

The clinical presentation of malrotation varies in older children and is often insidious. The most important malrotation group includes cases with histories of non-specific gastrointestinal symptoms, such as intermittent abdominal pain, vomiting, feeding problems, constipation, or diarrhea. These patients are often diagnosed with a milk allergy, malabsorption, irritable bowel syndrome, celiac disease or even a psychiatric disorder. Such presentations may lead to an erroneous interpretation and delay the diagnosis and proper treatment. ${ }^{3-6,9}$

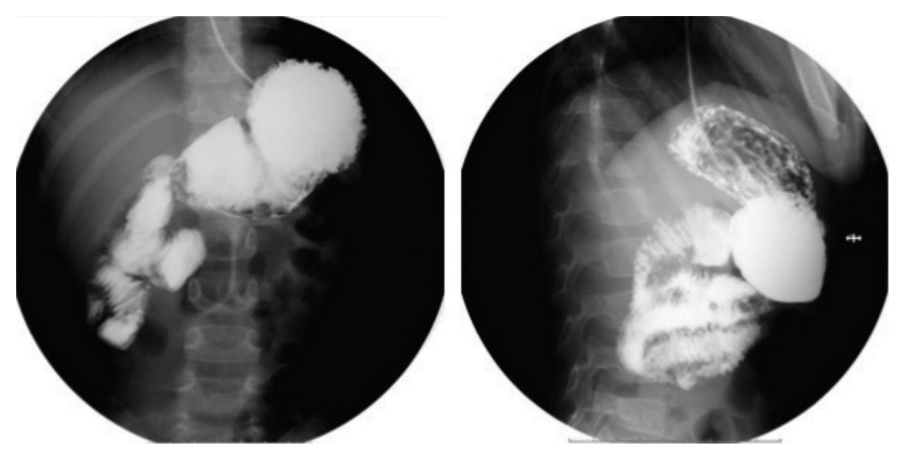

Figure 1. Esophagography with barium 
The present case of malrotation had no symptoms until the age of 4 years. She stopped eating after her father slapped her one month before admission. Unfortunately, her complaints began at the same time with this conflict. The diagnosis was missed at another center, as there were many concurrent psychiatric symptoms. The patient's oral food intake improved after the operation, and the psychiatric symptoms resolved. This case emphasizes that an organic disorder can be confused with a mental disorder. In conclusion, intestinal malrotation may present at any age and includes atypical symptoms, and the clinicians should consider all symptoms to avoid missing this important and treatable condition.

\section{Acknowlegment}

We are very thankful to all colleagues at Department of Pediatrics and Pediatric Surgery at Başkent University Adana Dr.Turgut Noyan Medical and Research Center for sharing their pearls of wisdom with us during the course of this case.

\section{Ethics}

Informed Consent: Written informed consent was obtained from the legal guardian of the patient for the article.

Peer-review: Internally peer reviewed.

\section{Authorship Contributions}

Conflict of Interest: No conflict of interest was declared by the authors.
Financial Disclosure: The authors declared that this study received no financial support.

\section{References}

1. Stockmann PT. Malrotation. In: Oldham KT, Colombani PM, Foglia RP, Skinner MA, eds. Principles and Practice of Pediatric Surgery (2nd ed). Philadelphia; Lippincott Williams \& Wilkings; 2005:1283.

2. Spigland N, Brandt ML, Yazbeck S. Malrotation presenting beyond the neonatal period. J Pediatr Surg. 1990;25:1139-1142.

3. Cohen Z, Kleiner O, Finaly R, Mordehai J, Newman N, Kurtzbart E, Mares AJ. How much of a misnomer is "asymptomatic" intestinal malrotation? Isr Med Assoc J. 2003;5:172-174.

4. Nehra D, Goldstein AM. Intestinal malrotation: varied clinical presentation from infancy through adulthood. Surgery. 2011;149:386-393.

5. Fonkalsrud E. Rotational anomalies and volvulus. In: O'Neill JA, ed. Principles of Pediatric Surgery. St. Louis: Mosby; 2003:477.

6. Lin JN, Lou CC, Wang KL. Intestinal malrotation and midgut volvulus: A 15-year review. J Formos Med Assoc. 1995;94:178-181.

7. Pine DS. Systems Neuroscience. In: Thapar A, Pine DS, Leckman JF, Scott S, Snowling MJ, Taylor EA, eds. Rutter's Child and Adolescent Pyschiatry. Wiley Blackwell; 2015:119-131.

8. Aboagye J, Goldstein SD, Salazar JH, Papandria D, Okoye MT, AlOmar K, Stewart D, Lukish J, Abdullah F. Age at presentation of common pediatric surgical conditions: Reexamining dogma. J Pediatr Surg. 2014;49:995-999.

9. Ezer SS, Oguzkurt P, Temiz A, Ince E, Gezer HO, Demir S, Hicsonmez A. Intestinal malrotation needs immediate consideration and investigation. Pediatr Int 2016;58:1200-1204. 